\title{
EFFECTS OF OVARIECTOMY ON THE PLASMA PROGESTERONE AND MAINTENANCE OF GESTATION IN THE BLUE FOX, ALOPEX LAGOPUS
}

\author{
O. M. MØLLER \\ Department of Reproductive Physiology and Pathology, \\ Veterinary College of Norway, Postbox 8146 Oslo-Dep., Norway
}

(Received 28th September 1973)

\begin{abstract}
Summary. Four blue fox vixens were ovariectomized at different stages of pregnancy. Ovariectomy resulted in an abrupt fall in the peripheral plasma progesterone levels. About 2 days after ovariectomy, blood and/or fetuses were noticed in the respective pens, indicating that removal of the ovaries in this species terminates gestation.
\end{abstract}

No information seems to be available about the effects of ovariectomy on the plasma progesterone and maintenance of gestation in the blue fox. The presence of morphologically active CL during gestation does indicate, however, that in this species the ovaries play a rôle in the synthesis and secretion of progesterone throughout pregnancy (O. M. Møller, unpublished data).

In this study, six blue vixens aged from 2 to 4 years were used. The vixens came into heat between the 5 April and the 9 May. Oestrus lasted at least 4 days, and the vixens were mated twice, i.e. the 3 rd and the 4 th day of acceptance.

Blood samples were taken between 09.00 and 10.00 hours, and were processed as described previously (Møller, 1973). The sampling was started before the onset of oestrus, and daily samples were taken from four animals on the last days of pro-oestrus and during oestrus. Later, the sampling was more infrequent. Blood samples were taken from all the vixens immediately before laparotomy and $2 \mathrm{hr}$ after the operation.

Four of the vixens were ovariectomized through a mid-line incision under pentobarbitone sodium anaesthesia (Nembutal, Abbott Laboratories, 25 to 35 $\mathrm{mg} / \mathrm{kg}$ ); ligatures were placed around the ligaments and their vessels, and the ovaries were removed. The last two vixens were subjected to sham operation. In all the vixens, both ovaries contained many $\mathrm{CL}$, and, as judged from the appearance of the uteri, four of the animals were pregnant. In two vixens, the pregnancies were not proven, probably due to the short time which had elapsed from coitus, i.e. 14 days and 17 days post coitum (p.c.).

Duplicate measurements of progesterone on the plasma samples were 
performed by a rapid competitive protein-binding technique described by Johansson (1969) with minor modifications by Fylling (1970). The routine work was carried out exactly as previously described by Møller (1973). The coefficient of variation was $10.9 \%$ between 1.25 and $5 \mathrm{ng}$, and $8.7 \%$ between 5 and $10 \mathrm{ng}$ on the standard curve.
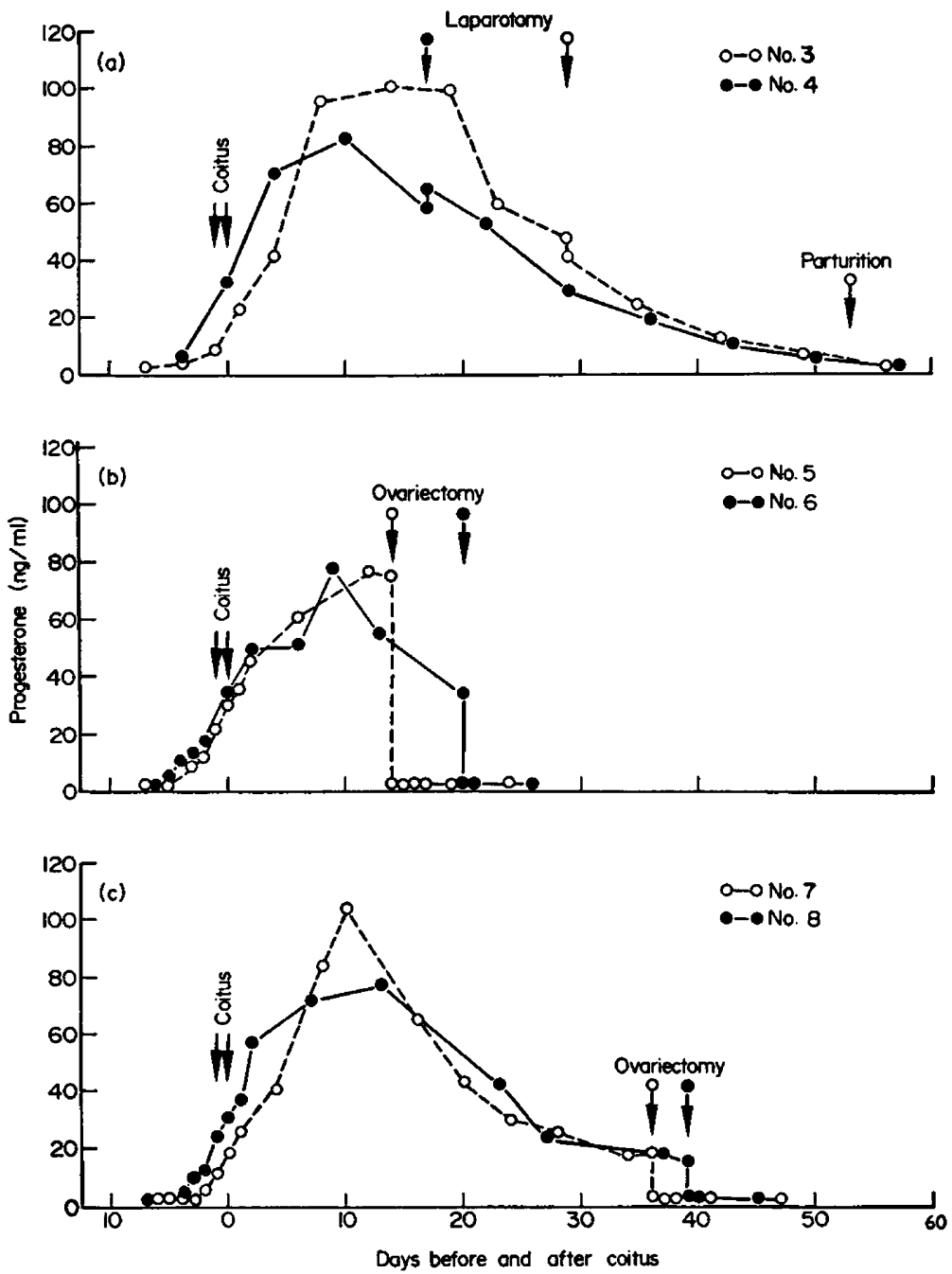

TEXT-FIG. 1. Plasma progesterone concentrations of blue fox vixens (a) subjected to sham operation on Day 17 (No.4) and Day 29 p.c. (No. 3) or (b,c) ovariectomized on Day 14 (No. 5), Day 20 (No.6), Day 36 (No.7) and Day 39 p.c. (No. 8). Vixen No. 3 gave birth to whelps on Day 53 p.c., while No. 4 did not show any signs of delivery or abortion. Signs of abortion were noticed in all the ovariectomized vixens 2 days after surgery.

The progesterone values and profiles obtained from the two vixens subjected to sham operation (Text-fig. la) showed the same pattern as that previously observed in corresponding intact animals (Møller, 1973). The operation on Vixen No. 4 was on Day 17 p.c. No signs of gestation were observed, and this 
animal did not give birth to whelps at term. The operation on Vixen No. 3 was on Day 29 p.c. and this vixen littered six whelps 24 days later. From the present results, it seems reasonable to assume that laparotomy per se did not interfere with progesterone secretion or the maintenance of gestation. Text-figure 1 (b) shows the progesterone profiles obtained from two vixens (No. 5 and No. 6) which were ovariectomized on Day 14 p.c. and Day 20 p.c., respectively. Vixen No. 6 was proved to be pregnant, but Vixen No. 5 was not. In the plasma samples taken immediately before ovariectomy, the progesterone levels were $74 \mathrm{ng} / \mathrm{ml}$ in Vixen No. 5 and $33 \mathrm{ng} / \mathrm{ml}$ in No. 6. At $2 \mathrm{hr}$ after ovariectomy, the progesterone levels in both cases were found to be below 2.5 $\mathrm{ng} / \mathrm{ml}$. Blood was noticed in the pens 2 days after the operation, indicating that both animals had probably aborted. Text-figure 1 (c) shows the progesterone profiles obtained from two pregnant vixens (No. 7 and No. 8) ovariectomized on Day 36 and Day 39, respectively. Even in these vixens, the plasma progesterone fell significantly after ovariectomy: from $17 \mathrm{ng} / \mathrm{ml}$ to below $2.5 \mathrm{ng} / \mathrm{ml}$ in No. 7, and from $15 \mathrm{ng} / \mathrm{ml}$ to below $2.5 \mathrm{ng} / \mathrm{ml}$ in No. $8 \mathrm{by} 2 \mathrm{hr}$ after ovariectomy. Both vixens aborted fetuses 2 days later, indicating that ovariectomy causes abortion even if the operation is performed as late as 14 days before term.

From the results of the present investigation, it is obvious that the transfer of progesterone from the placenta to the maternal circulation is very small in the blue fox and that the placenta does not produce enough progesterone to maintain pregnancy. It may be assumed, therefore, that in this species an obligatory relationship exists between luteal function and the maintenance of pregnancy.

Further information about day-to-day changes in the plasma progesterone levels at the time of sexual receptivity was also obtained. In Vixens No. 5 and No. 8, the progesterone concentrations increased 1 day before the onset of oestrus. In No. 6 and No. 7, however, there seemed to be a good degree of correlation between the beginning of the behavioural manifestation of oestrus and the increased secretion of progesterone (Text-fig. $1 \mathrm{~b}$ and $\mathrm{c}$ ). The source of this preovulatory increase of progesterone (ovulation is thought to occur on the 3rd and/or 4th day of sexual receptivity) is probably the ripe preovulatory follicle. In the silver fox, the membrana granulosa appears to assume luteal characteristics before ovulation (Pearson \& Enders, 1943).

\section{REFERENCES}

Fylling, P. (1970) The effect of pregnancy, ovariectomy and parturition on plasma progesterone level in sheep. Acta endocr., Copenh. 65, 273.

Johansson, E. D. B. (1969) Progesterone levels in peripheral plasma during the luteal phase of the normal human menstrual cycle measured by a rapid competitive protein binding technique Acta endocr., Copenh. 61, 592.

Mølner, O. M. (1973) Progesterone concentrations in the peripheral plasma of the blue fox (Alopex lagopus) during pregnancy and the oestrous cycle. $\mathcal{F}$. Endocr. 59, 429.

Pearson, O. D. \& Enders, R. K. (1943) Ovulation, maturation and fertilization in the fox. Anat. Rec. 85,69 . 